\title{
Politics and Language Rights: A Case Study of Language Politics in Croatia Vanessa Pupavac
}

\begin{abstract}
This chapter discusses language and national aspirations through a case study of language politics in Croatia. Not only is language crucially influenced by national politics, but language politics has played a significant role in national politics in which the status accorded to regional variations in language has paralleled political aspirations. Claims to a distinct Croatian language and rejection of a shared Serbo-Croatian language have been a key part in the Croatian nation-building process of the last decade. Yet recognition of Croatian as a distinct language implies recognition of Serbian minority language rights for ethnic Serbs in Croatia. Accordingly Croatia specified Serbian as one of its minority languages on ratification of the 1992 European Charter for Regional or Minority Languages. Since ratification Croatia has been criticised by European and international bodies for failing to comply with minority language rights provisions for its ethnic Serbs. However, the chapter contends that the international approach towards minority language rights provision is fundamentally flawed and its criticisms misdirected. Rather than enhancing the position of ethnic Serbs in Croatia, minority language rights are inappropriate and detrimental to their interests.
\end{abstract}

\section{Language and statehood}

Eric Hobsbawm argues in Nations and Nationalism Since 1780 that 'Languages multiply with states; not the other way round' (1992: 63). Since Hobsbawm's book was published a decade ago, we have witnessed the demise of the status of a shared Serbo-Croat language and its multiplication into four separate languages Bosnian, Croatian, Montenegrin and Serbian, alongside the collapse of former Yugoslavia and the creation of new separate states. The language question in the region has been intimately bound up with the state of South Slav relations, often prefiguring political developments (Greenberg 1996). The Croatian linguist Ivo Pranjković has pointedly observed that 'the perpetual politicisation of our standard idioms and Croato-Serbian relations must be borne in mind' (Pranjković 1993: 106). ${ }^{1}$ The accordance of language or dialect status has paralleled political aspirations endorsing Hobsbawm's statement. In essence, the assertion of a common language with regional variations has been associated with South Slavism and the aspiration for a common state, while the assertion of distinct languages reflects ethnic divisions and the aspiration for separate states.

This paper analyses how language debates and linguists themselves have become entangled in politics through a case study of language politics in Croatia. Nevertheless, setting aside politics, linguistics does have general criteria for determining the existence of distinct languages in relation to morphology, syntax and so on. Linguistically, following the sociolinguists Robert Greenberg and Kenneth Naylor, not only do Croats, Bosniacs and Montenegrins and Serbs share a common language, but they share the same dialect according to where they live or come from, although the ethnicised nature of dialectologists' studies has sought to demonstrate otherwise (Greenberg 1996; Naylor, 1992, 1996). ${ }^{3}$ Moreover, regional variations were objectively more marked between Zagreb and Belgrade in the nineteenth century than today. However, the more minor distinctions of today loom far larger in the collective imagination than the greater disparities of yesteryear did for their nineteenth century forebears. 
A useful summary for the general reader of the main regional differences in the language appears in Celia Hawkesworth's Colloquial Serbo-Croat (1986):

There are three main dialects of Serbo-Croat, one of which was selected as the literary language in the mid-nineteenth century. This dialect is known as štokavian because in it the word for 'what' is što. (The other two are known as kajkavski and čakavski because in them the word for 'what' is respectively kaj and ča). Within štokavian, there are two major subdivisions, most conveniently described as the Western and the Eastern variant. The main distinguishing feature of these is the way in which a particular early Slavonic vowel sound has evolved: into $\mathbf{e}$ in the Eastern variant, and je or ije (depending on the length of the vowel) in the Western variant, e.g. mleko (milk) and mlijeko. The variants are thus known as ekavski and jekavski (or ijekavski). (There is a further sub-dialect, ikavski, spoken mainly on the Dalmatian coast, in which the word for 'milk' is mliko. This is not accepted as standard speech, however). There are certain other differences [...] These inevitably include some lexical variations, resulting from centuries of separate development. For example, the word for the basic foodstuff 'bread' is kruh in the Western and hleb in the Eastern variant (xviii, bold in the original).

Here one should note the richness of regional dialects within Croatia: for kajkavian belongs to northern Croatia, and čakavian to the Adriatic islands and part of the coast, in addition to the ikavian dialect of the Dalmatian coast. In short, while the standard language of Croatia is the Western variant of štokavian written in the Latin script, there is much regional language variation within Croatia but these differences are not being politicised: underscoring how linguistics is often secondary in determining the status accorded to differences.

Not only is language crucially influenced by national politics, but language politics has played a significant role in national politics. Claims to a distinct Croatian language have been a key part of the Croatian nation-building process in the 1990s. ${ }^{2}$ As such, Croatia is a useful case to study Hobsbawm's statement on the influence of politics on language claims and the link between the recognition of language and statehood. Indeed, linguistic disputes first publicly manifested discontent among the Croatian elite with its relations with Belgrade. Accounts of Croatian secession often refer to the language question in the sequence of events.

First we defended the constitutional provisions on the Croatian language, then we formed an independent Croatian state, then we made the Croatian literary language completely independent, we established a military force and then we created chaos in the once shared language. As our soldiers would say, we crushed Serbo-Croat as a literary language like an old tin can (Pavičić 1995: 18).

This statement by a journalist published in the Croatian newspaper Vjesnik encapsulates how the language issue is no arcane academic matter but is central to the national question in the region. The journalist's comments demonstrate how the establishment of Croatian as a separate language is explicitly linked to the Croatian state-building process. In this context, the assertion of a common language is associated in Croatian politics today with claims to a Greater Serbia, although nineteenth century Croatian intellectuals had pioneered the idea as part of the Illyrian movement. 
Codification of a Croatian standard language, as in other languages, involves contention over which linguistic forms are included or excluded. Noting the importance of distinguishing a Croatian language from the formerly shared Serbo-Croat language, this process has involved the exclusion of particular vocabulary or linguistic forms associated with Serbs, rather than words viewed as merely dialect or vernacular. Hence controversy over the norms of the standard language is ethnicised. As a Croatian grammar of the mid-1990s states, the Croatian language 'serves as a way for Croats to demonstrate and recognise themselves as Croats' (Težak et al 1994: 27).

However, local politics have not been the only determining factor in the language controversies of the last decade. An additional neglected factor has been the influence of identity politics on international policy-makers and policy assumptions. In brief, the sources of violent conflict are increasingly traced to 'human needs of recognition and identity' (Burton 1997: 31). Consequently, subjective identity claims including language have been treated sympathetically by international organisations in the last decade as part of conflict management. Recognition of Croatian as a distinct language also implies recognition of Serbian as a distinct language, creating a minority language rights question in relation to the ethnic Serbs in Croatia. All across the region, recognition of distinct Bosnian (or Bosniac), Croatian, Serbian and more recently Montenegrin languages has been accompanied by counter-demands by ethnic minorities for distinct minority language rights. In Croatia, the ethnic Serbian politician Milorad Pupovac of the Serbian Democratic Forum, who originally trained as a linguist, ${ }^{4}$ has demanded recognition of Serbian language rights (Pupovac 1992: 17). While in Vojvodina, ethnic Croatian leaders have demanded recognition of Croatian language rights and called for the Vojvodina authorities to provide Croatian language classes in schools (Stantić 1997). Likewise in Bosnia, the three main ethnic groups have been demanding to be taught in their own language. In areas following the Bosnian government curriculum, ethnic Croatian leaders have objected to ethnic Croatian pupils being taught in the Bosniac language and demanded that they be taught in Croatian (Ravlić 1995).

The standard language in schools is an obvious theme in language disputes. In addressing the relationship between politics and language, I highlight how political developments are reflected in the changing treatment of the language in Croatian grammars. Official approval is required for textbooks used in schools; therefore they illustrate official policy and the norms of the standard language as well as politics in different periods. That school textbooks embody national identity at a particular moment is evocatively described by the Croatian writer Dubravka Ugrešić in her essay 'My First Primer' (1998). Examination too of continuity and change in authorship, that is, of the officially approved linguists, indicates both continuity and change in the bureaucracy under regime transformation. Certain prominent linguists have managed to bridge regime transformation, not merely adapting their linguistic positions to the contemporary political climate but actually remaining key ideologues of the new politics and its manifestation in linguistic policies.

For reasons of space, my analysis is necessarily brief and can only highlight particular works and issues as representative of official policy and the politicisation of language. That grammars can assume great political significance is illustrated by the political storm surrounding the publication of a Croatian Orthography in 1971. The textbook was not regarded by the federal authorities as 'a mere orthographic rulebook', but was viewed by the Central Committee of the Communist Party of Croatia as a 'nationalist act of sabotage' challenging the state of Yugoslavia (quoted in Babić et al 1984: iv). All copies of the text 
were ordered to be destroyed, and the orthography became a cause célèbre of the Croatian émigré community who sponsored its publication abroad (ibid.).

The 'politics of dialects' in former Yugoslavia (Greenberg, 1996) has both historical precedents and contemporary parallels: contention over the relationship between Dutch and Flemish, to name one example, or British and American English, to name another. Yet such parallels are usually overlooked. The present depoliticisation of the language question between America and Britain allows classical accounts of the history of the English language to glide over historical moves for linguistic independence such as Noah Webster's $1783 \mathrm{~A}$ Grammatical Institute of the English Language or his 1842 Dictionary of the American Language. So Robert Burchill's classic work The English Language asserts an unproblematic history of English that contrasts sharply with the language politics of the post-Yugoslav states:

There are no constitutional processes leading to declarations of linguistic independence as there are in politics. No flags are run up as signs or symbols of linguistic sovereignty. There are not governor-generals of language, and no linguistic Boston Tea Parties (Burchill 1985: 160).

Yet Burchill's confident disavowal of linguistic Boston Tea Parties ignores the political significance of past declarations of linguistic independence such as Webster's campaign for an American orthography (Simpson 1986: 52-56). Webster deplored continuing American cultural dependence on Britain and considered that the American Revolution could not be complete unless there was sovereignty 'in manners', cultivated by American publishing (ibid.). Radical declarations of linguistic sovereignty were ultimately overridden by internal politics: the spectre of Babel loomed larger for American intellectuals than the distant British state (Simpson 1986: 46-48). Namely, a linguistic declaration of war against British English norms might lead not to an American standardisation but to anarchy in the language and the state. As Webster himself is often quoted as stating, 'Our political harmony [...] is concerned in a uniformity of language' (in Gustafson 1992: 313). Always tempered by internal political and security concerns, declarations of American linguistic independence lacked momentum once the United States felt securely established as an independent state. Thus later publications symbolised both statements of independence from and reconciliation with British English. 'If the speller was America's Declaration of Linguistic Independence', the language historian Thomas Gustafson declares, Webster's dictionary 'was a linguistic Treaty of Paris wherein Webster maintains that while a difference of language between England and America is inevitable, a sameness is desirable' (ibid.: 320), illustrating the significance of grammars for statehood.

The post-Yugoslav states do not yet feel securely established and are experiencing a 'Thucydidean moment': 'a time when words are perceived to be not a representative sign of ideas but a sovereign duplicitous force' (ibid.). In these circumstances, language debates are dominated by political concerns, rather than linguistic realities, until such time as the new states and the ethnic groups within them no longer feel insecure and threatened. So while the competing demands for language rights may not make linguistic sense and lack linguistic necessity, these demands do make political sense for they help legitimise political claims, both domestically and internationally. In the case of ethnic minorities, language rights claims relate to claims for political inclusion through a specifically recognised status. As such, the proliferation of language rights demands is the logical consequence of both domestic and international politics of recognition and their codification of identity-based rights. In this 
shared elevation of identity, international responses to the language question in the postYugoslav states have tended to endorse nationalist language politics, which international policy-makers are now attempting to unravel. International officials are, for example, attempted to de-ethnicise the language issue in Bosnian schools by approving language textbooks euphemistically entitled Naš jezik [Our Language] (Gazibara and Zekić 2002). I begin by discussing post-war Yugoslav language politics.

\section{Language politics in SFR Yugoslavia}

Mindful of the experiences of the Second World War, post-war Yugoslavia sought to prevent nationalist politics by depoliticising and defusing ethnicity. Extensive recognition of identity, such as the codification of Macedonian as a literary language, was promoted to accommodate ethnic sentiment. The handling of the Serbo-Croat language spoken by four of the officially recognised nations of Yugoslavia who represented approximately three-quarters of the population was considered of vital significance to the legitimacy and cohesion of the state (Bugarski 1995: 16-17). In the 1950s there were moves to coordinate standardisation of the language in the two ekavian and ijekavian variants, aiming to reconcile the need for a standard with the symbolic significance of the two predominant Croatian and Serbian literary language traditions, representing the two most populous ethnic groups in the country. This standardisation of the language in more than one variant may be observed in relation to Armenian, Greek and Hindu-Urdu (Haughen 1972: 107). In 1954 the Novi Sad Agreement declared that the language was one:

The national language of Serbs, Croats and Montenegrins is one language, that is, the literary language which developed from its basis around two main centres, Belgrade and Zagreb, united, with two pronunciations, ijekavian and ekavian (cited in Pravopis 1960: 9).

The agreement stated that the Cyrillic and Latin scripts were equal and that both scripts should be learnt from the first grade in school. The Novi Sad Agreement was followed up in 1960 with an Orthography of the Serbo-Croat Literary Language (Aleksić et al 1960), a joint project involving the universities of Belgrade, Sarajevo and Zagreb and published in ekavian and the Cyrillic script by the Serbian Matica Srpksa in Novi Sad, and in ijekavian and the Latin script by the Croatian Matica Hrvatska in Zagreb. Joint work was also begun on a Dictionary of the Serbo-Croatian Literary Language. Following on from the Novi Sad Agreement, the 1963 Constitutions of Bosnia and Herzegovina, Montenegro and Serbia denominated the official language as Serbo-Croatian, and that of Croatia as Croato-Serbian.

Yet the Novi Sad Agreement only held sway for a decade before the language question was publicly re-opened in the mid-1960s with acrimony over the first two volumes of the Dictionary of the Serbo-Croatian Literary Language submitted to Matica Hrvatska and Matica Srpska. Croatian academics accused the joint dictionary project inter alia of representing the Serbianisation of the language in its treatment of certain vocabulary in standard use in Croatia as dialect words. At the same time, the existing Orthography of the Serbo-Croatian Literary Language (Aleksić et al 1960) was also attacked for not sufficiently taking into account Croatian orthographic practice, although it had received praise when it was first published for its sensitive treatment of the two variants. That the treatment of particular linguistic forms as non-standard should fuel linguistic disputes is unsurprising, given the symbolic significance of inclusion and exclusion of linguistic forms. The treatment of a term as merely dialect, that is non-standard, is to give it an inferior status as language 
'excluded from polite society', as Haughen observes (Haughen 1972: 100). However, there was an unwillingness to work on a linguistic solution.

The dispute escalated quickly beyond linguistics and became icons of Croatian intellectuals' general discontent with their position in the state, culminating in the 1967 Declaration on the Name and the Position of the Croatian Literary Language. The Declaration was significant because it was signed by prominent figures: 18 Croatian institutions and 140 Croatian intellectuals including the Croatian writer Miroslav Krleža and others who had signed the 1954 Novi Sad Agreement, as well as members of the Central Committee. In the Declaration Croatian intellectuals rejected the 1954 Novi Sad Agreement as a denial of the Croatian literary heritage and declared Croatian and Serbian to be separate literary languages and demanded that the Constitution recognise four literary languages: Croatian, Macedonian, Serbian and Slovenian. While the Declaration addressed language, the document effectively represented the declaration of the Croatian Spring nationalist movement demanding a revision of Croatia's status within Yugoslavia. The Croatian academic Radoslav Katičić wrote in the weekly Hrvatski Tjednik in 1971:

This agreement rests on the unsupported assumption of an alleged Serbo-Croat linguistic unity, which has frequently been used to deny the independent existence of the Croat literary language and its historical and territorial continuity (quoted in Babić et al, 1984: xvi).

These demands then led to counter-demands by 42 Serbian intellectuals who in a Proposal for Consideration of the same year demanded measures to protect the Cyrillic script from encroachment. This rift was never overcome despite dissenting academics on both sides. Cooperation between Matica hrvatska and Matica srpska over the joint dictionary project was not resumed. While the first three volumes of the Dictionary of the Serbo-Croatian Literary Language were published jointly by Matica hrvatska and Matica srpska in 1967, 1967 and 1969 respectively, the subsequent volumes were published in the 1970s by Matica srpska alone. A pattern emerged in dialectology studies of Croatian assertion of a distinct literary language and Serbian assertion of a distinct dialect belonging to ethnic Serbs within Croatia which distinguished them from their fellow Croatian citizens (Greenberg 1996).

Croatian concern to secure the position of the Croatian literary language manifested itself in the revised 1974 constitutional provisions. The provisions of the three other relevant republics shifted towards the idea of a shared hyphenated title or titles for the language. However, the idea of shared hyphenated title or titles was now mistrusted as creeping Serbianisation by the Croatian elite. The constitutional provision for Croatia sought to guarantee officially the existence of the Croatian literary language to appease national sentiment, but at the same time retain the previous constitutional provision 'Croatian or Serbian': 'The Croatian literary language - the standard form of the national language of the Croats and Serbs living in Croatia, which is called Croatian or Serbian'. The Constitutional Court of Yugoslavia held that the provision on the Croatian literary language was ambiguous since it was not clear whether the provision referred to one or two standard languages (discussed in Bugarski 1995: 58-61).

This provisional ambiguity and the cautious response of the Constitutional Court demonstrate how there was nervousness about both the evident politicisation of the language and how this politicisation might be confronted. The authorities vacillated between taking a tough or a more tolerant line. Severe responses were meted out to the use of the term 'Croatian 
language', leading to the pulping of Croatian Orthography. But officials were inconsistent in relation to the term 'Croatian literary language'. Authors found they got contradictory responses from different officials as to whether the term was or was not acceptable. Publication was prevented of a revised and renamed sixth edition of Overview of the Grammar of the Croatian Literary Language (1973) (Težak and Babić 1994), which had previously gone under the title Overview of the Grammar of the Croato-Serbian Literary Language (Težak and Babić 1966). Yet other works were published using the term 'Croatian literary language'.

Language disputes were not resolved and intensified from the mid-1980s as political divisions manifested themselves in grievances over language rights. In Slovenia, the use of Serbo-Croat as the official language of the Yugoslav People's Army (JNA) and military courts galvanised Slovenian public opinion against the federal authorities in the notorious Mladina trials. In Serbia, the infamous 1986 Memorandum drafted by members of the Serbian Academy of Arts and Sciences singled out Croatian language aspirations as a threat to the language and position of ethnic Serbs in Croatia (Croatian Information Centre 1994: 71). As these language disputes intensified, academics, such as the Croatian linguist Dubravko Škiljan, called for better coordination on the standardisation of the language to ensure valid concerns were addressed. One of the last symbolic initiatives was a special monograph under the title Language, Serbo-Croatian, Croato-Serbian, Croatian or Serbian (1988) co-authored by the leading Croatian linguist Dalibor Brozović and the leading Serbian linguist Pavle Ivić. Nevertheless such initiatives had little impact on the course of the disputes or even some of the authors of these joint projects who went on to espouse nationalist positions. Brozović, for example, became politically active in the new regime as a member of Franjo Tudjman's ruling HDZ party and was a member of the Croatian Presidency in 1990 involved in changing the Croatian Constitution. Alongside the new constitution came a new Law on Primary Education (1990) under which it was declared that teaching was to be in the Croatian language. With new language norms came new grammars, although the authors were often familiar names and the grammars re-workings of previous editions.

The next section contrasts the treatment of the language in a sample of Croatian grammars past and present.

\section{Croatian grammars past and present}

Official school grammars of the postwar period such as Grammar of the Croato-Serbian Language (Brabec et al 1965) followed the position of the Novi Sad agreement. Not only was the language treated as unified in the present, but from its very codification as a literary language. Texts emphasised the joint cooperation between Croatian and Serbian intellectuals in developing the modern literary language. Moreover, primacy was given to the commonality of the spoken word over distinct literary traditions (Babic 1967: 86-87). Regional distinctions in accent and vocabulary were not regarded as significant. In particular, the ekavian and ijekavian distinction was minimalised as sub-categories of the shared štokavian dialect adopted by both Zagreb and Belgrade as the standard (Babić 1967: 51 and 90; Brabec et al 1965).

In contrast, authorised grammars of the last decade in Croatia declare the existence of a distinct Croatian language evidenced primarily on the use of ijekavian and the Latin script, and particular vocabulary, morphological and orthographic differences. Cooperation in the 
establishment of the standard written language is ignored or downplayed. Comparing the diametrically opposed accounts in the post-1990 Grammar of the Croatian Language (Težak and Babic 1994) to the earlier editions of Introductory Grammar of the Croato-Serbian Literary Language (Težak and Babić 1966) makes interesting reading given that authorship remains the same. The later edition strongly refutes the common language thesis of the earlier editions, stating that the issues of mutual comprehension, shared structure and stokavian dialect are irrelevant and merely obscure the existence of a distinct Croatian language:

Theoretically, its singularity is obscured by the fact that it is so closely related to the Serbian literary language that they can be understood almost completely without translations. This is because both are based on the stokavian dialect and share a common structure and the main body of vocabulary (Težak and Babić 1994: 16).

Yet, in the face of the official position on ekavian as distinguishing Serbian from Croatian as a language, ekavian is nevertheless regarded as one of the accents of Croatian in their grammar (ibid.: 18-19), underscoring the importance of politics in language debates.

In this last section, I will consider the issue of language for ethnic Serbs in Croatia with the demise of the idea of a shared language.

\section{Minority language rights for Serbs?}

With the official divorce of the language and the declaration that teaching in schools was to be in the Croatian language, a requirement was logically created under both domestic and international minority rights provisions to provide Serbian language classes to ethnic Serbs in Croatian schools. Human rights advocates from Amnesty International, Helsinki Committee and other organisations have criticised Croatia for not respecting the language rights of its ethnic Serbian minority by not providing special language provision. Yet would one demand special language provision for ethnic Britains in the United States or vice versa? Criticisms of the lack of special language provision and policy proposals for special language rights misrepresent the interests of ethnic Serbs in Croatia and are highly inappropriate for addressing their needs.

The minority rights model ironically endorses the nationalist declarations on the language question as opposed to linguistic criteria. While the work of foreign linguists has not supported nationalists' language claims (Škijan, 2000: 6), the identity rights-approach of foreign diplomats, human rights advocates and conflict mediators has unfortunately tended to legitimise nationalist language claims and minority exclusions. The very designation of a separate minority language status for ethnic Serbs is to be excluded from the standard and thus set apart from mainstream society or 'polite society', borrowing again from Haughen (1972: 100). While ethnic leaders may press for special minority rights and become included in the public sphere as recognised community representatives, it is not advantageous overall for ordinary ethnic Serbs. In the aftermath of a war in which Serbia was regarded by the Croatian authorities as the aggressor, few ethnic Serbs want to bring undue attention to themselves by identifying themselves with the enemy nation.

To illustrate the concerns of ordinary ethnic Serbs, I will briefly highlight issues raised in informal interviews conducted between 1996-1998 with ethnic Serbian teachers and parents about schooling. The first group concerns the views of ethnic Serbs in Eastern Slavonia 
during the period of transition under UN supervision. Ethnic Serbs in Eastern Slavonia form a more cohesive population, than ethnic Serbs elsewhere in Croatia who are politically and socially atomised, and their demands differed accordingly. These ethnic Serbs were still demanding a degree of autonomy during negotiations over the return of Eastern Slavonia to Croatia. International human rights advocates have tended to translate these demands into cultural and language rights. However, the right to cultural self-determination did not motive demands for autonomy, although it may be recalled that certain parts of Eastern Slavonia are ekavian speaking. The main preoccupation of teachers was whether the Croatian authorities would recognise their teaching qualifications or experience recognised by the former Republika Srpska Krajina authorities. The teachers expressed anxiety that if a degree of autonomy were not recognised, the Croatian authorities might sack ethnic Serbian teachers who did not have all the requisite teaching qualifications or experience. It is not uncommon for teachers to lack officially required teaching qualifications because of the war and the brain drain out of teaching to better paid work. As a result of the shortage of qualified teachers, education ministries have allowed the recruitment of staff who have not completed all their training or without requiring them to do so. Consequently, the position of many teachers would be jeopardised were the authorities to insist on the officially required qualifications. Their anxiety was not unfounded given that a previous Croatian minister had recommended only pure Croats should teach the Croatian language (Ugrešić: 1998: 62). In essence, their concerns were about equality before the law, not special language rights.

Subsequently, it may be noted that the majority of schools designated officially as teaching in Serbian are located in Eastern Slavonia (Ministry of Education and Sport 2000b: 35). Yet what is the advantage to pupils of separate language provision? Effectively the special treatment marks pupils off from their contemporaries and hinders their acceptance into mainstream Croatian society. That recognition of distinct languages is a barrier to the reintegration of pupils in schools and the reconstruction of ethnic coexistence is an issue international officials have belatedly acknowledged and trying to tackle across the border in Bosnia. One indicator of whether ethnic Serbian pupils in these designated schools feel integrated in Croatian society is whether they decide in the future to pursue higher education and careers in Croatia or opt instead for study and employment in Serbia.

That the minority rights model course might be viewed as problematic as a strategy is suggested by the responses of ethnic Serbs elsewhere in Croatia. Ethnic Serbs outside Eastern Slavonia expressed individualised responses to the issue of schooling. Individual teachers were unenthusiastic about being identified so publicly as ethnically Serb by being designated to teach the separate Serbian language, history and culture classes. Similarly individual parents were reluctant to send their children to such classes which might mark them out for bullying as members of the enemy aggressor nation. So while ethnic leaders may acquire security through a special minority leadership status, ordinary ethnic Serbs are seeking to be treated as ordinary Croatian citizens, many putting themselves down as Croatian in the latest census. They are not demanding special public provision to learn ekavian and the Cyrillic script or Serbian history and culture. Often overlooked by international human rights advocates is that outside of parts of Eastern Slavonia, ethnic Serbs will be ijekavian speakers and use the Latin script as their Croatian neighbours. In areas of Krajina before the war where the population was predominantly ethnically Serbian then locals were more likely to be confident reading in the Cyrillic script, because of the greater number of Belgrade newspapers, magazines and comics on sale locally than other parts of Croatia. However, even in a town such as Knin where the pre-war population was ninety per cent ethnically Serbian, it should be reiterated that people were ijekavian speakers and overwhelmingly wrote in the 
Latin script. It was only during the war under the Republika Srpska Krajina administration and its nationalist Serbian language policies that there was official adoption of ekavian and Cyrillic for public use. Public buildings and shops and cafes were supposed to change their signs, and school textbooks were imported from Serbia. Nevertheless, official language policy was frequently honoured in the breach, not least by officials who were themselves ijekavian speakers or whose staff lacked typewriters with keyboards for the Cyrillic script.

The sort of language recognition required by ethnic Serbs in Croatia is driven by practical needs and issues of equality. In particular, there has been a problem with official reluctance to recognise documents printed or written in Cyrillic such as past entries in municipal registers. Notably, ethnic Serbian refugees have had difficulties with the Croatian authorities recognising birth, marriage or death registry entries from the Republika Srpka Krajina period that appeared in Cyrillic. This has even been the case where it is clear from the official documentation that the same official has been involved in compiling the records through the regime changes, switching language norms as required by the incumbent authorities. Failure to recognise the records has meant in particular that ethnic Serbian children born in the early 1990s in areas under Republika Srpska Krajina control have been denied Croatian citizenship for a number of years. But again politics influences whether these entries are recognised as official records: Serbian language norms have not presented an insurmountable obstacle to ethnic Croats seeking to invoke these entries as official records. The issue here is one of equality before the law as in Eastern Slavonia. Insistence on Serbian minority language rights is not only inappropriate to address the needs of ethnic Serbs in Croatia, but is detrimental to their position in Croatian society.

\section{Depoliticisation of the language question?}

I have tried to illustrate here how language politics in Croatia is bound up with a 'Thucydidean moment', a crisis of statehood. A continuing sense of insecurity in Croatia and elsewhere in the post-Yugoslav states means that the possibility of depoliticising the language question in the near future remains elusive. Huge sensitivity in Croatia continues to be expressed about the language issue in the new millennium. A Ministry of Education discussion document warns:

Given all the negative experience gained through history it is essential to take into account the particular sensitivity of the Croatian School, of teachers and parents towards the need to shape and nurture national identity, particularly in the areas of language, material and spiritual culture, history and authentic heritage, and which is being wrongfully usurped by others (Ministry of Education and Sport 2000a: 18).

Until a sense of statehood is secure then efforts will continue to secure the language against its neighbours. That a sense of insecurity impels language wars and demands for language purification is evident in the historical development of other languages. The depoliticisation of the language question between Britain and the United States suggests the importance of security. It was a sense of secure statehood and improved political relations that facilitated reconciliation of British and American English. The international minority rights model would have complicated and hindered the process of resolution had it applied two centuries ago. International minority language rights initiatives are misdirected and merely compound the politicisation of language. It is time to revisit international minority rights approaches and 
to examine how they may be unwittingly fuelling the 'Thucycdidean moment' and legitimising ethnic divisions.

\section{Notes}

1. Extracts have been translated by the author of this paper unless otherwise stated.

2. The Croatian sociolinguist Dubravko Škiljan provides a fascinating account of Croatian linguistic identity. See Škiljan (2000).

3. I highly recommend Robert Greenberg's 1996 paper on the politics of dialects in former Yugoslavia, which provides an excellent overview of the language disputes and the literature on the subject.

4. See, for example, Pupovac's Jezici i politika (1988).

\section{Bibliography}

Aleksić, R. et al, 1960, Pravopis srpskohrvatskoga književnog jezika: sa pravopisnim rečnikom. [Orthography of the Serbo-Croatian literary language; with an orthographic dictionary] Novi Sad and Zagreb: Matica hrvatska and Matica srpska.

Babić, S., 1967, Školski lesikon obćeobrazovne škole: Jezik. [School lexicon for grammar schools] $3^{\text {rd }}$ edn. Zagreb: Panorama.

Babić, S.; B. Finka and M. Moguš, 1984, Hrvatski pravopis. [Croatian Orthography] London: Novo hrvatska.

Brabec, I.; M. Hraste and S. Živković, 1965, Gramatika hrvatskosrpskoga jezika. [Grammar of the Croato-Serbian language] $6^{\text {th }}$ edn. Zagreb: Školska knjiga.

Brozović, D. and P. Ivić, 1988, Jezik, srpskohrvatski/hrvatskosrpski, hrvatski ili srpski. [Language, Serbo-Croatian/Croato-Serbian, Croatian or Serbian] Zagreb: Jugoslavenski leksikografski zavod Miroslav Krleža.

Bugarsksi, R., 1995, Jezik od mira do rata. [Language from peace to war] Belgrade: Slovograf.

Burchill, R., 1985, The English Language. Oxford: Oxford University Press.

Burton, J. W., 1997, Violence Explained: The Sources of Conflict, Violence and Crime and their Provention. Manchester and New York: Manchester University Press.

Croatian Information Centre, 1994, Greater Serbia from Ideology to Aggression. Zagreb: Croatian Information Centre.

Gazibara, S. and Z. Zekić, 2002, Naš jezik za 5. razred osnovne škole. [Our language for the fifth year of primary school] Sarajevo: Svjetlost. 
Greenberg, R. D. 'The Politics of Dialects Among Serbs, Croats, and Muslims in the Former Yugoslavia.' East European Politics and Society, 10 (1996) 393-415.

Gustafason, T., 1992, Representative Words: Politics, Literature, and the American Language, 1776-1865. Cambridge: Cambridge University Press.

Hawksworth, Celia, 1986, Colloquial Serbo-Croat. London and New York: Routledge \& Kegan Paul.

Haughen, E., 1972, 'Dialect, Language and Nation', in Sociolinguistics: selected readings eds, J.B. Pride and J. Holmes. Harmondsworth: Penguin: 97-111.

Hobsbawm, E., 1992, Nations and Nationalism since 1780. $2^{\text {nd }}$ edn. Cambridge: Cambridge University Press.

Ministry of Education and Sport, Council of Education, Republic of Croatia, 2000a, The Basis for the Education System in the Republic of Croatia (Proposal for Discussion). Zagreb, June. http://www.see-educoop.net/

Ministry of Education and Sport, Institute for Educational Development, 2000b, Croatian Education System, Interim Report. Zagreb, June. http://www.see-educoop.net/

Naylor, K., 1992, 'The Sociolinguistic Situation in Yugoslavia with Special Emphasis on Serbo-Croatian', in Language Planning in Yugoslavia, eds R. Bugarski and C. Hawkesworth. Columbus: Slavica: 80-92.

Naylor, K., 1996, Sociolingvistički problemi među južnim slovenima. [Sociolinguistic problems among the South Slavs] Beograd: Prosveta.

Pavičić, J. 'I Srbi progovorili srpski.' [And Serbs speak Serbian] Vjesnik (8 October 1995) 18.

Pravopis srpskohrvatskoga kniževnog jezika, [Orthography of the Serbo-Croatian Language] 1960, Novi Sad: Matica srpka.

Pupovac, M., ed., 1988, Jezici i politike. [Language and Politics] Zagreb: Centar Vladimir Bakarić.

Pupovac, M., 1992, 'A settlement for the Serbs', in Breakdown: War and Reconstruction in Yugoslavia. London: Yugofax: 17-18.

Ravlić, I. 'Federacija na ispitu.' [The Federation is tested] Nedjeljna (22 September1995) 36.

Simpson, D., 1986, The Politics of American English, 1776-1850. New York: Oxford University Press.

Škiljan, D. 'From Croato-Serbian to Croatian: Croatian Linguistic Identity.' Multilingua, 19 (2000) 3-20.

Stantić, J. 'No Schools and No Status.' WarReport, 57 (1997) 32-33. 
Težak, S. and S. Babić, 1994, Gramatika hrvatskog jezika: priručnik za osnovno jezično obrazovanje. [Grammar of the Croatian Language: textbook for primary language education] Zagreb: Školska knjiga.

Težak, S. and S. Babić, 1966, Pregled gramatike hrvatskosrpskog jezika. [Introductory grammar of the Croato-Serbian language] Zagreb: Školska knjiga.

Ugrešić, D., 1998, Culture of Lies. London: Weidenfeld \& Nicholson.

Zakon o osnovnom školstvu, Narodne novine 59/1990 Zagreb.

Vanessa Pupavac is a Lecturer in Politics at the University of Nottingham. She has a background in law and area studies, and has previously worked for the International Criminal Tribunal for Former Yugoslavia and for the OSCE in Bosnia. Recent research has been examining the politics of recognition and international minority rights approaches. 